https://helda.helsinki.fi

\title{
Assessing the effectiveness of joint forest management in Southern Burkina Faso : A SWOT-AHP analysis
}

\section{Etongo, Daniel}

2018-05

Etongo , D , Kanninen , M , Epule , T E \& Fobissie , K 2018 , ' Assessing the effectiveness of joint forest management in Southern Burkina Faso : A SWOT-AHP analysis ', Forest Policy and Economics, vol. 90 , pp. 31-38 . https://doi.org/10.1016/j.forpol.2018.01.008

http://hdl.handle.net/10138/311083

https://doi.org/10.1016/j.forpol.2018.01.008

cc_by_nc_nd

acceptedVersion

Downloaded from Helda, University of Helsinki institutional repository.

This is an electronic reprint of the original article.

This reprint may differ from the original in pagination and typographic detail.

Please cite the original version. 


\title{
Assessing the effectiveness of joint forest management in Southern Burkina Faso: A SWOT-AHP analysis
}

Daniel Etongo $^{\mathrm{a}, \mathrm{b}, *}$, Markku Kanninen ${ }^{\mathrm{a}, \mathrm{c}}$, Terence Epule Epule ${ }^{\mathrm{d}}$, Kalame Fobissie ${ }^{\mathrm{a}, \mathrm{e}, \mathrm{f}}$

${ }^{a}$ Viikki Tropical Resources Institute (VITRI), Department of Forest Sciences, University of Helsinki, Helsinki, Finland

${ }^{\mathrm{b}}$ National Institute for Regional and Spatial Analysis (NIRSA), Maynooth University, Maynooth, Ireland

${ }^{\mathrm{c}}$ Center for International Forestry Research (CIFOR), Bogor 16115, Indonesia

${ }^{d}$ Department of Geography, McGill University, Burnside Hall 805 Sherbrooke St. W., Montreal, Quebec, Canada H3A 0B9

${ }^{\mathrm{e}}$ FOKABS Inc. Ottawa, Canada

${ }^{\mathrm{f}}$ University of Ottawa, School of International Development and Global Studies (SIDGS), Ottawa, Canada

\begin{abstract}
We analyzed the perceptions of resource persons from three stakeholder groups on the benefits, challenges and opportunities offered by joint forest management (JFM) in the Ziro province of Southern Burkina Faso. In other words, a strength, weaknesses, opportunities, and threats (SWOT) approach in combination with an analytic hierarchy process (AHP) was applied. Results reveal that resource persons of the three stakeholder groups perceive the positive aspects of JFM to outweigh the negative aspects. In addition, favorable institutional setup received the highest overall factor score for strength. Inadequate enforcement of the management plans is the weakness with the highest score and the overall priority score for weaknesses was highest for resource persons from the Ministry of Environment and Sustainable Development (MESD). On the other hand, better community relations received the highest overall factor for opportunities while uncertainty in decision making at higher levels was perceived as the most important threat to JFM in the Ziro province of Southern Burkina Faso. Therefore, differences in views and addressing realities on the ground requires the participation of all stakeholders in the design, implementation and follow-up of JFM to arrive at a consensus that is capable of delivering the twin challenges of environmental protection and rural development.
\end{abstract}

Keywords: Joint forest management, forest income, management plans, stakeholders' perception, SWOT-AHP, Southern Burkina Faso 


\section{Introduction}

Joint forest management (JFM) gained importance among policy makers, scientists and development practitioners in the 1980s as an approach that is capable of delivering the twin objectives of conservation and development (Brechin et al., 2002). The emergence of this approach was to address the gap of marginalization and in some cases the exclusion of local people from participating and benefiting from natural resources due to the top-down protectionist approach (Brown and Lassoie, 2010; Bhattacharya et al., 2010; Kamoto et al., 2013). Also, the attempt to exclude local people from designated forest reserves (Adams and Hulme, 2001), has caused leakages in some communities and thereby increasing the rate of deforestation and the loss of biodiversity (Guthiga, 2008). Involvement of local communities in collaboration with the government in forest management was considered the way forward for addressing the needs of the people while managing the forest sustainably (Mohanty, 2004; Brown and Lassoie, 2010).

With the potentials of JFM to deliver the above twin objectives, many developing countries started pursuing it with the aim of making forest management more effective, efficient and responsive to local needs (Larson and Ribot, 2004; Mohanty, 2004; Sandker et al., 2009). Burkina Faso embraced this initiative with initial JFM plans being implemented in the 1980s with the aim of supplying fuelwood to the major cities such as Ouagadougou, Koudougou and Bobo-Dioulasso (CoulibalyLingani et al., 2009). This initiative led to the creation of Forest Management Units (FMUs) managed by Forest Management Groups (FMGs). The FMGs are made up of community members and field staff from the Ministry of Forestry and the Ministry of Environment and Sustainable Development (MESD). An FMU is divided into fifteen parcels based on a fifteen-year-rotation period with a parcel expected to be logged once during the rotation cycle. This forest management model is expected to be effective and to guarantee supply of wood energy. However, there are some speculations from members of the technical department of the FMGs to increase the rotation period from fifteen to twenty years.

Increasing the rotation period of parcels within a FMU does not guarantee the effectiveness of JFM by default. Several factors have been identified to influence the performance of JFM programs in Ghana (Appiah, 2001) and India (Kumar, 2007). Sunderlin (2006) mentioned cooperation among stakeholders as one of such factors. However, it goes beyond cooperation and ignoring these factors sometimes might cause the program to fail (Singh et al., 2011). Two studies in Africa and Latin America indicated that the challenges associated with JFM have led to unsatisfactory results (Oyono, 2004; Stearman, 2006). Some of the key challenges relates to incompatibility of the 
technical, managerial and institutional requirements with local realities (Pokorny and Johnson, 2008). Furthermore, the cultural milieu of the area, opportunities to generate off-farm employment and economic activities, community capacity to undertake management responsibilities, and policy and institutional uncertainties have been identified to influence stakeholder's perceptions and involvement in JFM (Masozera et al., 2006; Singh et al., 2011; Dyer et al., 2014).

Although there have been some studies on factors influencing participation and performance in JFM in Burkina Faso (Hagberg, 2001; Yelkouni, 2004; Sawadogo, 2006; Coulibaly-Lingani et al., 2011; Coulibaly-Lingani et al., 2014), knowledge gaps still exist with respect to stakeholders' assessment of strengths, weaknesses, opportunities and threats (SWOT) as they pertain to JFM. Therefore, the objective of the current study is to assess the strengths, weaknesses, opportunities and threats of JFM. This is analyzed using an established SWOT analysis approach in combination with analytic hierarchy process (AHP) in the Ziro province, southern Burkina Faso as perceived by representatives of three stakeholder groups. To the best of our knowledge, this study is the first to verify the benefits, challenges and opportunities of JFM based on SWOT analysis and the analytic hierarchy process (AHP) in parts of the Ziro province of Burkina Faso.

\section{Study area and methods}

\subsection{The study area}

Participatory forest management programs were initiated in Burkina Faso in 1986. It started with assistance from a joint UNDP/FAO project with a focus on engaging local people in collaboration with the government to manage forest areas in the communities (Ribot, 1999). Joint forest management programs (Chantier d'Aménagement Forestier; CAF) were created in seven locations in the country. The Cassou zone located in the Ziro province is one of the seven JFM units that were created and is the focus of this study (Fig. 1). The Cassou zone was selected because of the presence of active FMGs, better opportunity to bring resource persons in since it is the provincial capital of the Ziro province and documented failures in different monitoring approaches. This province is found in southern Burkina Faso and is located $150 \mathrm{~km}$ from the capital city (Ouagadougou) and has an estimated area of $5291 \mathrm{~km}^{2}$. The region falls within the south-Sudanian phytogeographical zone and is characterized by low relief with an average altitude of $300 \mathrm{~m}$ above sea level. Annual rainfall ranges between $800-1000 \mathrm{~mm}$ with temperatures of between $30-35^{\circ} \mathrm{C}$. The main soil types are siltclay cambisols, sandy lixisols, and loamy ferric luvisols (Driessen et al., 2001). These soils and the climate support tree growth and agriculture with very little inputs. In addition, the average population density in the region is estimated at 28 inhabitants/km² (INSD, 2007). 
The population consists of autochthon/non-migrant (Gourounsi) and migrant ethnic groups (Mossi and Fulani). The Mossi originate from the central plateau while the Fulani from the north of the country. Given that the biophysical setting of the country exposes the central and northern region to recurrent droughts, migration of these two groups to the southern region has become a coping strategy. This is because approximate $70 \%$ of the country's population is rural and depend on agriculture and livestock for their livelihood. Subsistence traditional farming systems of cereal cultivation dominate the landscape together with cash crop cultivation (cotton and cashew) alongside fuelwood extraction and ranching. Woodfuels, mainly firewood and charcoal are harvested from community forests, woodlots, fallows and plantations and remains an important source of household energy in the country (Ouedraogo et al., 2015; Arevalo, 2016). Cattle herding is the main activity of the Fulani and agropastoral systems are common practices in this region and other parts of the country (FIP, 2012).

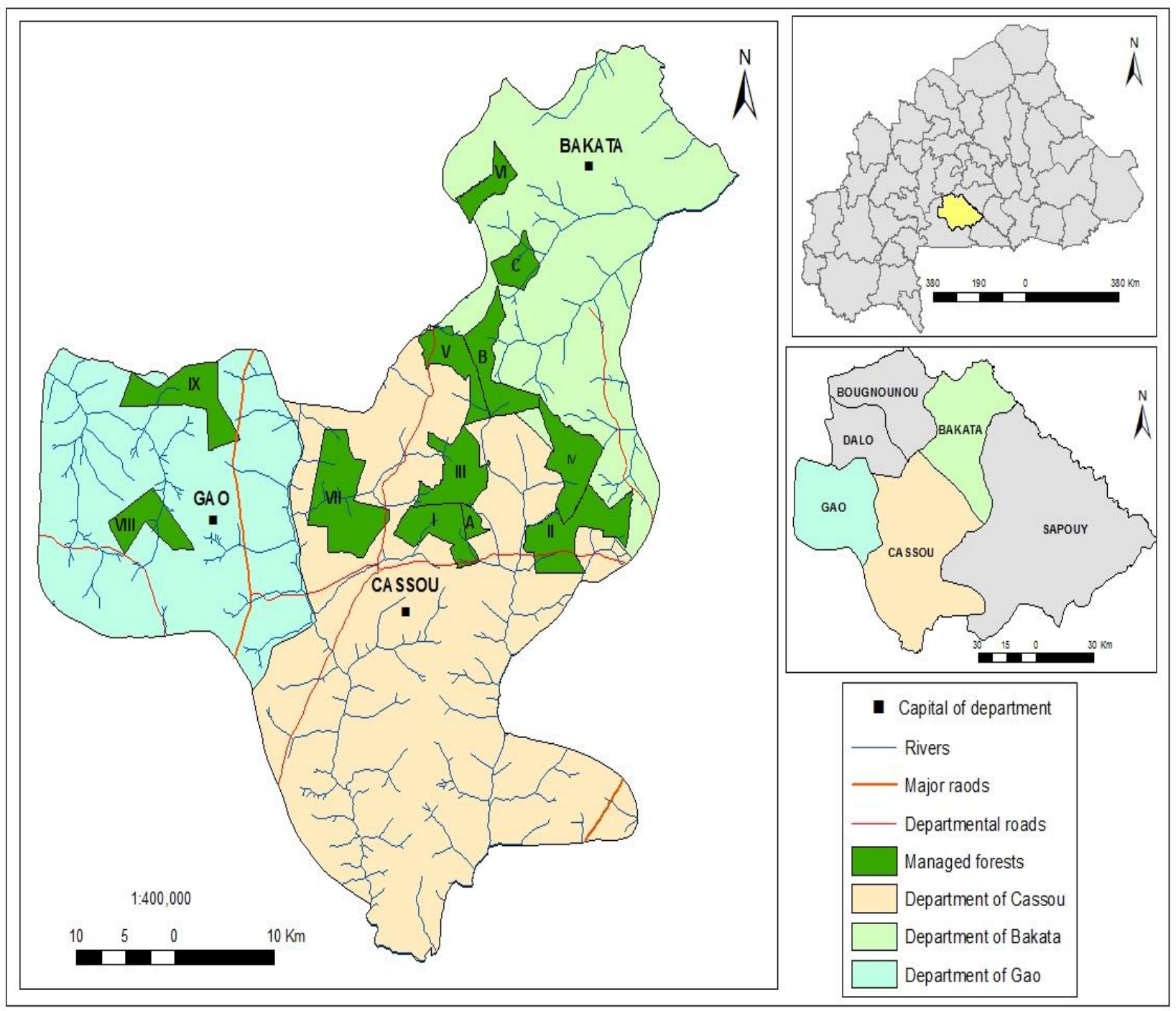

Fig. 1. Map of the study area showing managed forest in green 


\subsection{SWOT-AHP methodology}

The SWOT-AHP enhances systematic thinking and comprehensive diagnosis of factors relating to a new product, technology, management, or planning (Kurttila et al., 2000). This method has been considered invaluable in strategic planning with the advantage that all factors influencing the operational environment are diagnosed with greater detail (Hill and Westbrook 1997; Shrestha et al., 2004). In addition, it provides an opportunity to categorize factors into internal (strengths, weaknesses) and external (opportunities, threats) in relation to a decision and thereby enabling the comparison of opportunities and threats with strengths and weaknesses. A major limitation of the method is that the importance of each factor in decision-making cannot be measured quantitatively, thereby making it difficult to assess which factor influences the strategic decision most (Pesonen et al., 2000).

However, when used in combination with analytic hierarchy process (AHP), the SWOT approach can provide a quantitative measure of importance of each factor in decision-making (Saaty and Vargas, 2001; Ananda and Herath, 2003). The AHP method is flexible and enables decision makers to assign a relative priority to each factor through pair-wise comparison (Kurttila et al., 2000; Pesonen et al., 2000). The use of pair-wise comparison implies the application of the SWOT-AHP method is preferred on small sample sizes of individuals or groups that are knowledgeable with the issue under investigation (Kurttila et al., 2000; Ananda and Herath, 2003).

Kurttila et al. (2000) suggested three steps in conducting a SWOT-AHP analysis which were also applied in our study. The first step is for participants/stakeholder to identify key factors that influence the decision (see Fig. 2 for list of factors relating to JFM). It is suggested to keep less than 10 factors within each SWOT group for pair-wise comparisons to be manageable. In step two, pairwise comparison of factors within each SWOT group is conducted (see Fig. 3 indicating portions of the questionnaires used for pair-wise comparison). The main objective at this stage is to know which factor is more important and by how much based on a scale ranging from 1-9 (Saaty, 1996; Yüksel and Dağdeviren, 2007). As such, pair-wise comparisons will be conducted separately for all factors and a priority value for each factor is computed using the eigenvalue method (see appendix A for a detail procedure). The factor with the highest priority value under each SWOT group will be brought forward for further comparisons. Finally, the third step involves pair-wise comparison of four factors that are brought forward and computation of a scaling factor for each factor. The scaling factors and priority values are used to calculate the overall priority of each factor as follows: 
$=\left(\right.$ priority value of $\left.f_{i j}\right)$ (scaling factor of group $\left.{ }_{j}\right)$

Where $j=4$ (strength, weakness, opportunity, and threat). The overall score of all factors across groups sum to one and each score indicates the relative importance of each factor in decision.

\subsection{Implementing the SWOT-AHP}

We adopted the strengths, weaknesses, opportunities, and threats (SWOT) approach in combination with analytical hierarchy process (AHP) to achieve this task. SWOT analysis uses a diagnostic approach to identify key factors determining the success or failure of a plan or approach (Weihrich, 1982; Smith, 1999) while AHP on the other hand measures the relative importance of factors from stakeholders' point of view (Saaty, 1977, 1993). The implementation of the SWOT-AHP approach included the following stages that were also implemented in our study as follows: (i) the identification of key stakeholders involved in the decision process, (ii) classification of all the critical factors affecting the decision, and (iii) evaluation of the factors in each groups using the SWOT-AHP framework (Kurttila et al., 2000; Shrestha et al. 2004).

\subsection{Identification of stakeholders}

Formal and informal enquiries were made with key informants to gain information on potential opinion leaders involved in JFM at different levels. The stakeholders include resource persons from the local communities (non-members of forest management groups), FMGs (community members of FMGs and members of forestry department working in collaboration with the communities) and the MESD. Key informants included the youth leaders and chiefs in each of the villages and the field staffs of the Ministry of Forestry in the community forest villages. According to Robert (1991), those considered as opinion leaders must be maintained by technical competence, social accessibility and conformity to a system's norms. With assistance from key informants, a total of fifteen resources persons representing three stakeholder groups were selected as follows; 6 from local communities, 5 from FMGs and 4 from the MESD to assess their perceptions on the effectiveness of JFM in the Ziro province. The criteria for selecting a resource person / representative from the community were based on the ability of an individual to understand and express the community's views on the benefits, challenges faced and potentials of JFM in the region. The 6 community members selected were non-members of the FMGs. On the other hand, the five resource persons of the FMGs included 2 members from the community, the municipal 
administrator at the district level, a field staff of CAF at the district level and another CAF member from the national level (Ouagadougou). Finally, two of the participants of the MESD were from the provincial level while the other two were forest guards working with the same ministry at the provincial and district levels.

\subsection{Classification of decision factors}

The identification and classification of critical decision factors was accomplished through literature review, review of the forest management plans, field visits, in addition to the focus group discussion (FGD) amongst the fifteen participants from the three stakeholders group. An exhaustive list of SWOT factors relating to JFM was generated by the participants during a brainstorming session in Cassou, the departmental head of the province. The factors listed were further reviewed, deliberated, and organized into meaningful groups. For example, factors such as direct financial benefits limited to members of FMGs and lack of effective engagement of non-migrant groups associated with JFM were grouped as elite capture and considered a 'weakness' factor (see Fig. 2).

\begin{tabular}{|c|c|}
\hline Strengths & Opportunities \\
\hline S1: Favorable institutional setup & O1: Poverty alleviation \\
\hline -Decentralization process is a key to successful & -Socioeconomic improvement of communities. \\
\hline CFM. & -Off-farm source of income for livelihood \\
\hline S2: Source of additional income & diversification. \\
\hline $\begin{array}{l}\text {-Employment opportunities. } \\
\text {-Income generation through off-farm jobs. }\end{array}$ & $\begin{array}{l}\text { O2: Increasing awareness of the importance of forest in } \\
\text { communities }\end{array}$ \\
\hline S3: Elaborate forest management plan & O3: Better community-agency relationship \\
\hline $\begin{array}{l}\text {-Management plan adopts a fifteen-year rotation } \\
\text { cycle. }\end{array}$ & $\begin{array}{l}\text {-Relationships between communities and agencies } \\
\text { would improve. }\end{array}$ \\
\hline S4: Management benefits & O4: Improved management of buffer zones \\
\hline -Reduction of management cost. & -Communities involvement in reforestation activities. \\
\hline $\begin{array}{l}\text { Weaknesses } \\
\text { W1: Limited income generation } \\
\text {-Insufficient income from forest products. } \\
\text {-Widespread poverty in communities. } \\
\text { W2: Poor monitoring of community forest } \\
\text {-Few number of field staffs. } \\
\text { W3: Elite capture } \\
\text {-Direct financial benefits limited to members of } \\
\text { FMGs. } \\
\text {-Lack of effective engagement of non- } \\
\text { indigenous groups. } \\
\text { W4: Inadequate enforcement of management plan } \\
\text {-Current management plan is obsolete. }\end{array}$ & $\begin{array}{l}\text { Threats } \\
\text { T1: Uncertainty in relation to decision making at higher } \\
\text { levels } \\
\text {-Limited influence of communities in high-level } \\
\text { decision making. } \\
\text {-Limited influence of field staff over high-level } \\
\text { decisions. } \\
\text { T2: Expansion of farmlands into community forest } \\
\text {-Agribusiness development. } \\
\text {-Loss of biodiversity. } \\
\text { T3: High demand for wood energy } \\
\text {-Illegal exploitation of forest. } \\
\text { T4: Potential conflicts } \\
\text {-Potential conflicts within and between communities. } \\
\text {-Potential conflicts between communities and the } \\
\text { government. }\end{array}$ \\
\hline
\end{tabular}

Fig. 2. SWOT factor relating to JFM

After preparing the preliminary list of decision factors, they were categorized into16 major factors, four of which were placed in each SWOT group with input from the FGD (Fig. 2). Though 
considering many factors as possible might prove beneficial, the number of pair-wise comparisons in AHP grows exponentially as the factors increase. In order to keep pair-wise comparisons at a manageable level, we limited the SWOT category to a maximum of four key factors in each group.

\subsection{Evaluation of the factors}

Based on the SWOT factors listed in figure 2, survey questionnaires were developed for pair-wise comparison. These questionnaires included a rating scale of one to nine (Saaty, 1996; Yüksel and Dağdeviren, 2007) to weigh each factor relative to the other (Fig. 3). The questionnaire was administered to each of the three groups separately. During the pair-wise comparison, members in each group were asked to deliberate and evaluate SWOT factors in pairs and indicate if both factors are equally important or one is more important than the other based on the 1-9 scaling system (Fig. 3).

1. Compare STRENGTH 1 to STRENGTH 2, and circle one appropriate number.

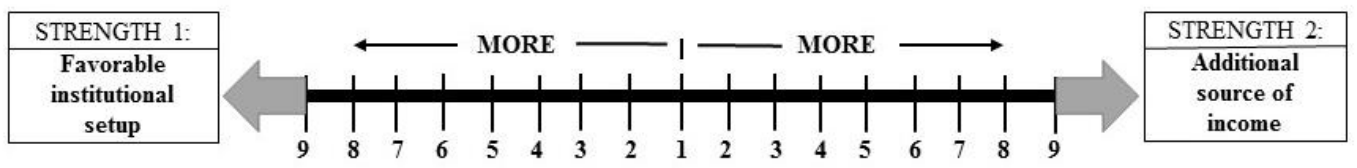

2. Compare STRENGTH 1 to STRENGTH 3, and circle one appropriate number.

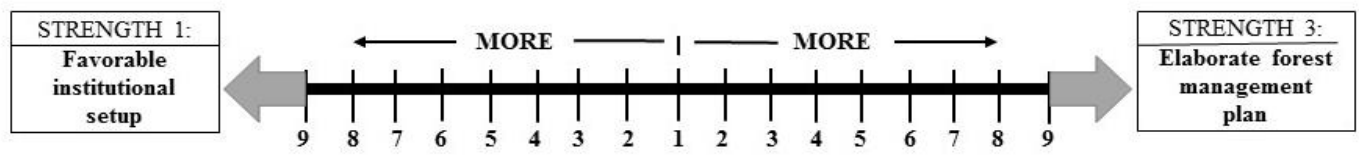

3. Compare STRENGTH 1 to STRENGTH 4, and circle one appropriate number.

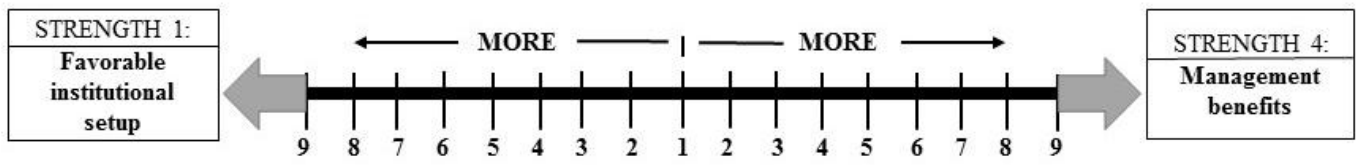

Fig. 3. Example of questionnaires for the pair-wise comparison based on strength factors.

In figure 3 question 1, if the response was "5" on the right side, it implies that "additional source of income" factor is five times more important than "favorable institutional setup" factor. Members were allowed to deliberate and come to a consensus in assigning a relative weight. Given the challenge of a unified position of agency or organizations due to the lack of policy statement on issues related to JFM, a "group consensus" approach was adopted. Based on this approach, the pairwise comparison process was repeated separately for each stakeholder group until all the SWOT factors were exhausted. The overall priority scores were calculated for each factor within each SWOT group going by our earlier explanation on the method. The consistency ratios throughout our 
analysis was kept below 0.1 as suggested by Saaty $(1977,1993)$. The data obtained from the three stakeholder groups were analyzed separately using Microsoft excel version 2013 to derive the factor priority and overall priority scores (Table 1).

\section{Results and discussion}

The overall priority scores of factors for the three stakeholder groups are presented in columns 5-7 of Table 1. Given that the overall priority scores add up to one, each priority score can be interpreted as weight of each factor for assessing the SWOT of JFM. In addition, scores of strength and opportunity factors can be interpreted as positive of JFM while the scores of weakness and threat factors as negatives. For example, overall priority scores of 0.443 and 0.343 (column 5 of Table 1) suggest that strengths and opportunities factors of JFM would account for $44 \%$ and $34 \%$ respectively. Strength factors (S1-S4) were assigned higher weighting than other SWOT factors. One possible explanation for the strength factors could be the long history of participatory approach at the community level thereby providing an enabling environment that is favorable to establish JFM, a view corroborated by another study in Burkina Faso (FIP, 2012).

Our results indicated that stakeholder groups view aspects related to JFM differently. The variation was more for the factor priority scores compared to the overall priority scores. The overall priority scores for community, FMGs and MESD in relation to strengths were $44 \%, 36 \%$ and $45 \%$ respectively. This result indicates that the community members and representatives of the MESD perceive JFM as an approach that has more strength in resource management compared to representatives of the FMGs. The next category of overall priority scores that were relatively higher was opportunities. The resource persons of the FMGs perceived more opportunities (36\%) than those from the community (34\%) and MESD (15\%). It should be noted that members and nonmembers of FMGs access benefits through different channels.

For the non-members of FMGs, they benefit from projects financed by the village council with the percentage of money allocated to the village from the sale of fuelwood from JFM. Some of the projects that were identified during the FGD in the study area include the construction of compost pits, a community school in Vrassan village and construction of village halls for meetings. On the other hand, members of FMGs get direct financial benefits from the sale of fuelwood in addition to the benefits they derive from community projects. Therefore, members of FMGs, be it at the community level or the government would perceive JFM as a program that enable them to get direct financial benefits as indicated by a study in Burkina Faso (Coulibaly-Lingani et al. 2014). The overall priority score for poverty alleviation $(0.084)$ is linked to members' perception from the 
MESD. This group compared to the others indicated that JFM has $84 \%$ opportunity of alleviating poverty. The MESD is an arm of the government whose agenda is in line with achieving the dual objectives of JFM - which is conservation and rural development. However, effective participation is needed to achieve these objections and according to Lise (2000), one of the prerequisites for successful collective action is active and effective participation of stakeholders at various levels of resource management.

Table 1

Factor priority scores and overall priority of SWOT-AHP analysis

\begin{tabular}{|c|c|c|c|c|c|c|}
\hline \multirow[t]{3}{*}{ SWOT groups } & \multirow{2}{*}{\multicolumn{3}{|c|}{ Factors priority scores }} & \multirow{2}{*}{\multicolumn{3}{|c|}{ Overall priority scores }} \\
\hline & & & & & & \\
\hline & Community & $\underline{\text { FMGs }}$ & MESD & Community & FMGs & MESD \\
\hline Strengths & & & & 0.443 & 0.367 & 0.451 \\
\hline S1: Favorable institutional setup & 0.397 & 0.175 & 0.187 & 0.176 & 0.642 & 0.084 \\
\hline S2: Source of additional income & 0.093 & 0.531 & 0.125 & 0.041 & 0.195 & 0.056 \\
\hline S3: Elaborate management plans & 0.234 & 0.158 & 0.555 & 0.104 & 0.058 & 0.250 \\
\hline S4: Management benefits & 0.276 & 0.137 & 0.121 & 0.122 & 0.050 & 0.055 \\
\hline Weaknesses & & & & 0.131 & 0.146 & 0.326 \\
\hline W1: Limited income generation & 0.181 & 0.212 & 0.234 & 0.024 & 0.031 & 0.076 \\
\hline W2: Poor monitoring of forest & 0.233 & 0.501 & 0.203 & 0.031 & 0.073 & 0.066 \\
\hline W3: Elite capture & 0.388 & 0.076 & 0.097 & 0.051 & 0.011 & 0.032 \\
\hline W4: Inadequate enforcement of... & 0.198 & 0.212 & 0.464 & 0.026 & 0.031 & 0.151 \\
\hline Opportunities & & & & 0.343 & 0.365 & 0.158 \\
\hline O1: Poverty alleviation & 0.106 & 0.288 & 0.532 & 0.036 & 0.105 & 0.084 \\
\hline O2: Increase awareness of the... & 0.246 & 0.283 & 0.115 & 0.084 & 0.103 & 0.018 \\
\hline O3: Better community relations & 0.541 & 0.349 & 0.242 & 0.186 & 0.127 & 0.038 \\
\hline O4: Improved management of... & 0.106 & 0.079 & 0.111 & 0.036 & 0.029 & 0.018 \\
\hline Threats & & & & 0.071 & 0.123 & 0.057 \\
\hline $\mathrm{T} 1$ : Uncertainty in relation to... & 0.256 & 0.333 & 0.147 & 0.018 & 0.041 & 0.008 \\
\hline T2: Expansion of farmlands into... & 0.298 & 0.248 & 0.454 & 0.021 & 0.031 & 0.026 \\
\hline T3: High demand for fuelwood & 0.091 & 0.271 & 0.209 & 0.006 & 0.033 & 0.012 \\
\hline T4: Potential conflicts within... & 0.356 & 0.131 & 0.190 & 0.025 & 0.016 & 0.011 \\
\hline
\end{tabular}

Note. Ministry of environment and sustainable development (MESD), Forest Management Groups (FMGs), while community include non-members of FMGs in the villages.

Figures in bold are factors of each SWOT group

Interpretation of the factor priority and overall priority scores of the other SWOT and stakeholder groups can be done in a similar way. The relative importance of each factor within each SWOT group provides valuable information for decision-making. For example, a priority value of 0.397 reported in column two (Table 1) indicates that community resource persons perceive that favorable 
institutional setup (S1) alone accounts for about $40 \%$ of the total strength of JFM. As such, collaborative actions in JFM is considered an approach that is capable of improving knowledge sharing and strengthening local capacity - a benefit perceived as the most important by community resource persons. This participatory approach in resource management is in line with Burkina Faso's strategy for growth and sustainable development that seek to tap all the national potential for the benefit for its citizens in national development (World Bank, 2010; IMF, 2012).

\subsection{Community representatives' perceptions}

Analysis of within-group factors for community representatives shows that favorable institutional setup is perceived as the most important strength of JFM with a priority score of 0.397 (Table 1). The most important opportunity factor as perceived by this group is better community relations with a priority score of 0.541 . It is believed that JFM have provided a common platform for different groups of stakeholders to work together. A good example is the creation of FMGs that consists of members from both the local communities and the government with the aim of joint management of forest resources. On the other hand, the most influential weakness factor as perceived by community representatives is elite capture with a priority score of 0.388 . Elaborating on elite capture, this group indicated the lack of effective engagement of migrant groups as members of FMGs. As such, non-members of FMGs as opposed to member are unable to access any form of direct financial benefits but indirectly they could benefit from community development projects. The perception of communities on elite capture and financial benefits are important factors influencing JFM and are consistent with the observations of Coulibaly-Lingani et al. (2011) that elite capture in JFM in Burkina Faso is linked to financial benefits derived from participation. Aside from financial incentive, a study in Ghana also found that communication plays an invaluable role for effective participation in JFM (Appiah, 2001).

Finally, potential conflicts within and between communities with the potential to collapse JFM was perceived as a critical threat with a priority score of 0.356 . Some FMUs overlap between communities (see FMU II, IV, V and B in Fig. 1). This does not only pose governance challenge but was identified during the FGD as zones of conflicts due to illegal exploitation by members of the said communities. In addition, the devolution of power through decentralization brought in a new stakeholder - the rural council. During our FGD its was mentioned that though the Mayors are part of the FMGs, they devote more attention on development and very little on conservation. It was also indicated that some parcels of land within JFM areas have been sold out to some influential elites for agribusiness development. Local authorities in some cases do not represent the local 
population or their space of discretion is so narrow that they have little effect on management - a view support by an earlier study in sub-Saharan Africa (Ribot et al. 2010). Therefore, devolution of power especially in relation to JFM initiatives does not often result to a win-win situation but might place a cost on local livelihoods and the environment. An earlier study in Cameroon (Oyono, 2004) that arrive at similar findings on challenges of decentralized forest management describe this paradox as one step forward, two steps back. Another study in India reaffirm that decentralization may be a manipulation by elites to serve their own interest (Bhattacharya et al., 2010). As stated by Ribot (2003), a combination of locally accountable representation and discretionary powers are invaluable for efficient and equitable use and management of natural resources which is not the case in our findings. Furthermore, across-group analysis of community representatives' perceptions shows the influence of strengths, opportunities, weaknesses and threats in decreasing order of magnitude (overall priority scores of $0.443,0.343,0.131$ and 0.071 ).

\subsection{FMGs members' perceptions}

From within-group analysis, representatives of FMGs perceive source of additional income as the most important strength with a priority score of 0.531 (Table 1). This indicates that financial benefits are an important incentive that influence participation in JFM. This finding corroborate one of the SCADD strategy that focuses on improving income and creating jobs as strengthening sustainable development (IMF, 2012). The second most important strength factor was favorable institutional setup. Just as the community's perception, this group also indicated better community relations as a major opportunity factor with a priority score of 0.349 . The most serious weakness with a factor priority score of 0.501 , was poor monitoring of community forest areas. This result is expected because during field survey and focus group discussions it was observed that while the national parks were monitored continuously, occasional visits were made to JFM sites. Encroachment of farmlands and illegal wood harvesting have become a common practice in the region since defaulters go unpunished. During a field visit, some forest management units (FMUs) were already converted to farmlands. A study in India recommended higher levels of local monitoring and enforcement of locally made rules if JFM is to succeed (Singh et al., 2011).

In addition, the FMGs members also perceived that uncertainty in relation to decision making at higher levels represent the greatest threat with a priority factor of 0.333 . In such situations, JFM is likely to operate under government imposed rules because central ministries specify in great detail what management plans must look like thereby undermining the notion of local autonomy (Ribot, 2003). This approach is contrary to the view that strong autonomy of rule-making at the local level 
is the key predictor for better forests that provide ecosystem goods and services to support local livelihoods (Singh et al., 2011). Two important threats perceived by this group of respondent include high demand for fuelwood and expansion of farmlands into managed forest thereby causing deforestation and forest degradation (factor priority score of 0.271 and 0.248 ). An estimated $70 \%$ of Burkina Faso's forests is located in the southwestern region and these regions offers better opportunities for rain-fed agriculture that has acted as a pull factor for human migration from the north and central regions affected by drought. Arable lands have become scare while field expansion have become a common practice. The finding corroborates that of a recent study in southern Burkina Faso in which unsustainable agricultural practices and fuelwood extraction were identified are the main drivers of deforestation and forest degradation (Arevalo, 2016).

Results from across-groups indicated that, FMGs representatives perceive the strength and opportunity group to be influential in the effectiveness of JFM compared to the other two SWOT groups. The cumulative score of each SWOT group indicates its relative importance compared to other groups (Figure 3). For members of FMGs, strength factors have about 53\% influence on JFM. However, the weakness factor is estimated at $50 \%$ which is almost same as the strength. Because the strength is as good as the weakness, their expected impact is likely to even out. With such results, the effectiveness of JFM becomes questionable because such findings are a clear indication that JFM is a two-edged sword with benefits and challenges.

\subsection{Representatives from MESD perceptions}

The analysis revealed that having an elaborate management plan for JFM was perceived as the most important strength by representatives of the MESD with a factor priority score of 0.555 . The current forest management plan is overdue for review and not consistent with realities on the ground. In was indicated during the FGD that the FMUs were re-classified in 2007 and some parcels were joint to form new units, while those that were considered too larger were divided and others allocated to communities for agriculture. These modifications are yet to appear in new forest management plans and are difficult to verify. Though the CAF model is considered a success story of JFM in West Africa based on it fifteen-year rotation cycle, the sustainability of this approach is questionable. An expert assessment in Burkina Faso recommended that an improved management plan alongside targeted interventions to reduce the ongoing deforestation and forest degradation should be developed (Arevalo, 2016).

Aside from the elaborate management plan, the other three strength factors had little differences and could be considered to be relatively the same. This group of stakeholders perceive inadequate 
enforcement of management plan as the most important weakness with a factor priority score of 0.464. Slow growing tree species are still part of the management plan of which fast growing species can ensure the sustainable of wood harvesting - a hypothesis supported by a study in Burkina Faso (Arevalo, 2016). The management plan is expected to be reviewed after every ten years but this has not been respected for the last ten years. Information gathered from the field shows that buffer-zone development still remains a challenge. One of SCADD's strategy is environmental sustainability that seeks to preserve, improve and develop the environment and natural resources (IMF, 2012). However, the existing of a strategy or policy does not mean implementation and therefore sound policies should be accompanied by their effective implementation. Poverty alleviation was perceived as the most important opportunity factor by representatives of the MESD. Joint forest management (JFM) offers opportunities for off-farm income and livelihood diversification for local communities. The poverty alleviation strategic framework of Burkina Faso emphasizes the need for collective action between the state and local regional authorities (World Bank, 2010).

Across-group analysis of factors by stakeholders from MESD indicated that strength factors are highly influential followed by weakness factors. This implies that while positive activities are ongoing on one hand, negative activities or challenges are also encountered on the other hand. The overall group priority scores for the SWOT in decreasing order of magnitude for members of MESD include strengths (0.451), weaknesses (0.326), opportunities (0.158), and threats (0.057) (see Table 1).

\section{Conclusions and future perspective}

This study uses the SWOT-AHP approach to address the benefits, challenges and opportunities of JFM in Burkina Faso. The scores of strength and opportunity factors based on stakeholders' perceptions are interpreted as positive to JFM. As such, the institutional setup presents an arrangement for participation that can generate better outcome through collaboration if utilized in an appropriate manner. In addition, opportunity factors such as poverty alleviation and better management of community forest areas were also visible in our findings. Therefore, forest income plays an important role for both livelihood diversification and improvement. It represents an opportunity that can be further developed to create off-farm employment. Furthermore, strengthening the capacity of community members by the technical team from the government can be achieved. Silvicultural knowledge and techniques on planting, replanting, thinning, assisted 
natural regeneration, fire damage control and buffer-zone management are likely to improve the effectiveness of JFM in Burkina Faso.

It is also important to note that differences in perceptions among the three stakeholders' groups were recurrent in our findings. Being that people's perceptions in different parts of the world is often conditioned by differences in environmental, social and political conditions, it is important that the methods used here be used in other regions of the world such as in Asia and Latin America to verify the benefits, opportunities and challenges offered by JFM or community forestry. The most important strength factor in these groups were favorable institutional setup (community representatives), additional source of income (representatives of FMGs), and elaborate management plans (representatives of MESD). Such results are likely to indicate that the benefits a group derives from a resource or the institutions they represent can influence their perceptions. Aside from the most important strength factors in each stakeholder group, the most important weaknesses identified are elite capture (community representatives), poor monitoring of community forest areas (representatives of FMGs), and inadequate enforcement of the management plans (representatives of MESD). Increasing the number of technical staffs and the frequent visit and monitoring of JFM units are important. Just one technical staff oversees the activities in the entire Cassou zone - a major weakness that was identified during the FDG. The government should engage the local communities and build their capacity to undertake monitoring activities which will be more effective because they live in the villages and understand the terrain. On the other hand, the effective participation of migrant groups in the FMGs can disentangle the effects of elite capture.

An issue that raises new sets of questions as regards the effectiveness of JFM in southern Burkina Faso and consequently its sustainability is to increase the rotation period from fifteen to twenty years. While this sound good with the potential of allowing enough time for trees to mature, without the right silvicultural interventions and strict enforcement of the management plans, the outcome is not likely to be different from the current situation. However, the current management plans are obsolete and the need for new forest management plans is overdue for almost a decade. It is possible that using obsolete management plans might not fit into the current situation on the ground which does not pose a question only on the effectiveness but also its sustainability. Areas for further research and action may include: (i) review of the current management plans, (ii) buffer-zone management in community forest management, (iii) political economy and silvicultural approaches for improved forest management, and (iv) tapping into the potentials of climate finance as an innovative source for financing forest management. 


\section{Appendix A}

Information derived from pair-wise comparisons can be represented as a reciprocal matrix of weights, where the assigned relative weight enters into the matrix as an element $a_{i j}$ and reciprocal of the entry $1 / a_{j i}$ goes to the opposite side of the main diagonal.

$\mathbf{A}=\left(a_{i j}\right)=\left[\begin{array}{cccc}W_{1} / W_{1} & W_{1} / W_{2} & \ldots & W_{1} / W_{n} \\ W_{2} / W_{1} & W_{2} / W_{2} & \ldots & \vdots \\ W_{n} / W_{1} & W_{n} / W_{2} & \ldots & W_{n} / W_{n}\end{array}\right]$

where rows indicate ratios of weights of each factor with respect to all others. In the matrix, when $i=j, a_{i j}=1$, i.e. the main diagonal elements of matrix is A.

When we multiply matrix A by the transpose of the vector of weights, $w$, we get the resulting vector $n w$ (Eq. 2).

$\mathrm{A} w=n w, \quad$ Where $\mathrm{W}=\left(W_{1}, W_{2}, \ldots, W_{n}\right)^{\mathrm{T}}$

Eq. (A. 2)

Eq. (2) can be rewritten as

$(A-n I) W=0$

Where $n$ is the largest eigenfactor $\lambda_{\max }=n$ is a necessary and sufficient condition for consistency. Inconsistency may arise when $\lambda_{\max }$ deviates from $\mathrm{n}$ due to inconsistent responses in pair-wise comparisons. Therefore, the matrix A should be tested for consistency using the formula

$C I=\left(\lambda_{\max }-n\right) /(n-1)$ Eq. (A. 4)

$C R=C I / R I$

Where $C I$ is the consistency index, $R I$ is random index $(\mathrm{RI})$ generated for a random matrix of order $n$, and CR is the consistency ratio (Saaty, 1993). The general rule is that CR $\leq 0.1$ should be maintained for the matrix to be consistent. Homogeneity of factors within each group, smaller number of factors within each group, and better understanding of the decision problem can improve the consistency index (Saaty, 1993). 


\section{Acknowledgments}

This research was funded by the Finnish Ministry of Foreign Affaire through the BIODEV Project (Building Biocarbon and Rural Development in West Africa). We would like to thank all the resource persons for sharing their knowledge with us during the workshop. Many thanks also to two anonymous reviewers and also to Dr. Hemant Ojha the Editor.

\section{References}

Adams, W.M., Hulme, D., 2001. If community conservation is the answer in Africa, what is the question? Oryx, 35: 193-200.

Ananda, J., Herath, G., 2003. The use of Analytic Hierarchy Process to incorporate stakeholder preferences into regional forest planning. Forest Policy and Economics 5, 13-26.

Appiah, M., 2001. Co-partnership in forest management: The Gwira-Banso joint forest management project in Ghana. Environment, Development and Sustainability 3: 343-360.

Arevalo, J., 2016. Improving woodfuel governance in Burkina Faso: The experts' assessment. Renewable and Sustainable Energy Reviews 57: 1398-1408.

Bhattacharya, P., Pradhan, L., Yadav, G., 2010. Joint forest management in India: Experiences of two decades. Resources, Conservation and Recycling 54, 469-480.

Brechin, S.R., Wilshusen, P.R., Fortwangler, C.L., West, P.C., 2002. Beyond the square wheel: Toward a more comprehensive understanding of biodiversity conservation as social and political process. Society and Natural Resources 15:41-64.

Brown, H.C.P., Lassoie, J.P., 2010. Institutional choice and legal legitimacy in community-based forest management: lessons from Cameroon. Environmental Conservation 37 (3): 261-269.

Coulibaly-Lingani, P., Tigabu, M., Savadogo, P., Oden, P.C., Ouadba, J.M., 2009. Determinants of access to forest products in southern Burkina Faso. Forest Policy and Economics 11: 516-524

Coulibaly-Lingani, P., Savadogo, P., Tigabu, M., Oden, P.C., 2011. Factors influencing people's participation in the forest management program in Burkina Faso, West Africa. Forest Policy and Economics 13: 292-302.

Coulibaly-Lingani, P., Tigabu, M., Savadogo, P., Odén, P.C., 2014. Participatory forest management in Burkina Faso: Members' perception of performance. Journal of Forestry Research 25(3): 637-646.

Driessen, P., Deckers, J., Spaargaren, O., 2001. Lectures Notes on the Major Soils of the World. FAO World Soil Resources, Report-94. Food and Agriculture Organization of the United Nations: Rome, Italy.

Dyer, J., Stringer, L.C., Dougill, A.J., Leventon, J., Nshimbi, M., Chama, F., Kafwifwi, A., Muledi, J.I., Kaumbu, J.M.K., Falcao, M., Muhorro, S., Munyemba, F., Kalaba, G.M., Syampungani, S., 2014. Assessing participatory practices in community-based natural resource management: 
Experiences in community engagement from southern Africa. Journal of Environmental Management 137: 137-145.

FIP, 2012. Forest Investment Program. REDD Preparation Plan, Ministry of Environment and Sustainable Development, Burkina Faso. Accessed online on the $1^{\text {st }}$ January 2015 at http://www.forestcarbonpartnership.org/sites/forestcarbonpartnership.org/

Guthiga, P.M., 2008. Understanding local communities' perceptions of existing forest management regimes of a Kenyan rainforest. International Journal of Social Forestry, 1: 145-166.

Hagberg, S., 2001. In search of "nyo": Lyela farmers' perceptions of the forest in Burkina Faso. Journal of the International African Institute 71: 481-501.

Hill, T., Westbrook, R., 1997. SWOT analysis: it's time for a product recall. Long Range Planning $30(1), 46-52$.

International Monetary Fund (IMF), 2012. Burkina Faso: Strategy for accelerated growth and sustainable development 2011-2015. Available at https://www.imf.org/external/pubs/ft/scr/2012/cr12123.pdf

INSD., 2007. Résultats préliminaires du recensement général de la population et de l'habitat de 2006. Institut National des Statistiques et de la Démographie (INSD), Direction de la Démographie: Ouagadougou, Burkina Faso.

Kamoto, J., Clarkson, G., Dorward, P., Shepherd, D., 2013. Doing more harm than good? Community based natural resource management and the neglect of local institutions in policy development. Land Use Policy 35, 293-301.

Kumar, C., 2007. Perceptions of incentives for participation: Insights from joint forest management in India. International Journal of Sustainable Development \& World Ecology 14(5): 532-542.

Kurttila, M., Pesonen, M., Kangas, J., Kajanus, M., 2000. Utilizing the analytic hierarchy process AHP in SWOT analysis - a hybrid method and its application to a forest-certification case. Forest Policy and Economics 1, 41-52.

Larson, A.M., Ribot, J.C., 2004. Democratic decentralization through a national resource lens: An introduction. European Journal of Development Research, 16(1): 1-25.

Lise, W., 2000. Factors influencing people's participation in forest management in India. Ecological Economics 34: 379-392.

Masozera, M.K., Alavalapati, J.R.R., Jacobson, S.K., Shrestha, R.K., 2006. Assessing the suitability of community-based management for the Nyungwe Forest Reserve, Rwanda. Forest Policy and Economics 8: 206-216.

Mohanty, R., 2004. Institutional dynamics and participatory spaces: The making and unmaking of participation in local forest management in India. IDS Bulletin 35.2; New Democratic Spaces? Available online at http://www.drc-citizenship.org/system/assets/1052734413/original/1052734413 mohanty.2004-institutional.pdf?1289390559. 
Ouedraogo, I., Mbow, C., Balinga, M., Neufeldt, H., 2015. Transition in land use architecture under multiple human driving forces in a semi-arid zone. Land 4: 560-577.

Oyono, P.R., 2004. One step forward, two steps back? Paradoxes of natural resources management decentralization in Cameroon. The Journal of Modern Africa Studies 42: 91-111.

Pesonen, M., Kurttila, M., Kangas, J., Kajanus, M., Heinonen, P., 2000. Assessing the priorities using A'WOT among resource management strategies at the Finnish Forest and Park Service. Forest Science 47(4), 534-541.

Pokorny, B., Johnson, J., 2008. Community forestry in the Amazon: The unresolved challenges of forests and the poor. Overseas Development Institute, United Kingdom, Natural Resource Perspective 112: 1-4.

Ribot, J.C., 1999. Decentralization, participation and accountability in Sahelian forestry: legal instruments of political-administrative control. Africa 69: 23-65.

Ribot, J.C., 2003. Democratic decentralization of natural resources: Institutional choice and discretionary power transfer in sub-Saharan Africa. Public Administration and Development 23: 5365 .

Ribot, J.C., Lund, J.F., Treue, T., 2010. Democratic decentralization in sub-Saharan Africa: Its contribution to forest management, livelihoods, and enfranchisement. Environmental Conservation 37(1): 35-44.

Robert, J., 1991. The possibilities of accountability. Accounting, Organizations and Society, 16(4): 355-368.

Saaty, T.L., 1977. A scaling method for priorities in hierarchical structure. Journal of Mathematical Psychology 15, 234-281.

Saaty, T.L., 1993. The analytic hierarchy process: a 1993 overview. Central European Journal of Operation Research and Economics 2(2): 119-137.

Saaty, T.L., 1996. Decision making with dependence and feedback: The Analytic Network Process. RWS Publications, Pittsburgh.

Saaty, T.L., Vargas, L.G., 2001. Models, Methods, Concepts and Applications of the Analytic Hierarchy Process. Kluwer Academic Publisher, Boston, MA.

Sandker, M., Campbell, B.M., Nzooh, Z., Sunderland, T., Amougou, V., Defo, L., Sayer, J., 2009. Exploring the effectiveness of integrated conservation and development interventions in a Central African forest landscape. Biodiversity Conservation. DOI: 10.1007/s10531-009-9613-7

Sawadogo, L., 2006. Adapter les approaches de l'aménagement durable des forêts sèches aux aptitudes sociales, économiques et technologiques en Afrique. Le cas du Burkina Faso. Center for International Forestry Research, Jakarta, Indonesia. p. 59

Shrestha, R.K., Alavalapati, J.R.R., Kalmbacher, R.S., 2004. Exploring the potential for silvopasture adoption in south-central Florida: an application of SWOT-AHP method. Agricultural Systems 81, 185-199. 
Singh, V.S., Pandey, D.N., Prakash, N.P., 2011. What determines the success of joint forest management? Science-based lessons on sustainable governance of forests in India. Resources, Conservation and Recycling 56: 126-133.

Smith, J.A., 1999. The behavior and performance of young micro firms: evidence from businesses in Scotland. Small Business Economics 13, 185-200.

Stearman, A.M., 2006. One step forward, two steps back: The Sirionó and Yuqui community forestry projects in the Bolivian Amazon. Human Organization 65 (2): 156-166.

Sunderlin, W.D., 2006. Poverty alleviation through community forestry in Cambodia, Laos, and Vietnam: An assessment of the potential. Forest Policy and Economics 8: 386-396.

Weihrich, H., 1982. The TOWS matrix - a tool for situation analysis. Long Range Planning 15(2), 54-66.

World Bank, 2010. Local development, institutions and climate change in Burkina Faso: Situation analysis and operational recommendations. Available at http://siteresources.worldbank.org/BurkinaReportFinal_EN.pdf

Yelkouni, M., 2004. Gestion d'une resource naturelle et action collective: le cas de la forêt de Tiogo au Burkina Faso. Thèse de Doctorat en science économique. Université d'Aubergne - Clerrmont 1. Ecole Doctorale de Science Economique et de Gestion. 330 p.

Yüksel, I., Dağdeviren, M., 2007. Using the analytic network process (ANP) in a SWOT analysis A case study for a textile firm. Information Sciences, 177: 3364-3382. 